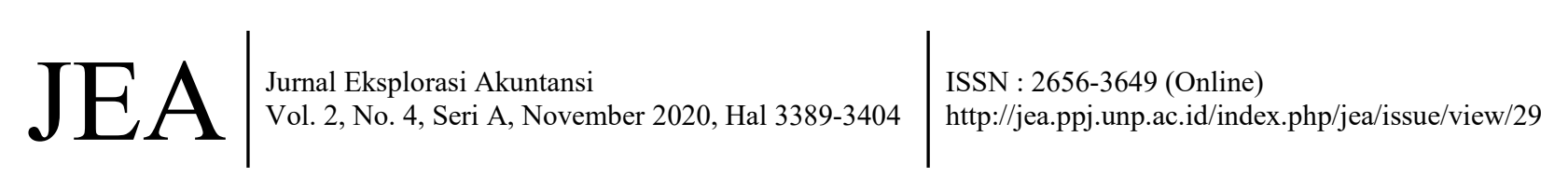

\title{
Pengaruh Ukuran Pemerintah, Opini Audit Dan Terpilihnya Kembali Kepala Daerah Sebelumnya (Petahana) Terhadap Audit Delay Pada Pemerintah Provinsi Di Indonesia
} (Studi Empiris pada Pemerintah Provinsi di Indonesia Periode 2014-2018)

\author{
Abriany Vanesha ${ }^{1}$, Efrizal Syofyan ${ }^{2}$ \\ ${ }^{1}$ Alumni Jurusan Akuntansi, Fakultas Ekonomi, Universitas Negeri Padang \\ ${ }^{2}$ Jurusan Akuntansi Fakultas Ekonomi Universitas Negeri Padang \\ *Korespondensi: abrianyvanesha05@gmail.com
}

\begin{abstract}
Financial statements that were not provided on time may cause those report loses their capacity to influence decisions. This study aims to examine the effects of goverments size, audit opinion, incumbent on audit delay in indonesia. This study used 165 financial reports from 33 provincial goverment in indonesia from 2014-2018. Researc data was obtained from the financial audit agency and directorate general of financial balance. The dependent variable of this researc is audit delay. While the independent variables include the size of goverment, audit opinion dan incumbent. Multiple regresion analysis was used to tes the hypothesis. The test results show that audit opinion has a significant effect on audit delay. But size of goverment and incumbent does not have a significant effect on audit delay.
\end{abstract}

Keywords: Audit delay, Finacial Report, Governmental Size, Audit Opinion dan Incumbent.

How to cite (APA $6^{\text {th }}$ style):

Vanesha, A \& Syofyan, E. (2020). Pengaruh Ukuran Pemerintah, Opini Audit dan Terpilihnya Kembali Kepala Daerah Sebelumnya (Petahana) Terhadap Audit Delay Pada Pemerintah Provinsi Di Indonesia (Studi Empiris Pada Pemerintah Provinsi di Indonesia Periode 2014-2018). Jurnal Eksplorasi Akuntansi, 2(4), Seri A. 3389-3404.

\section{PENDAHULUAN}

Laporan keuangan pemerintah memberikan informasi yang berguna bagi pengguna dalam menilai akuntabilitas dan pengambilan keputusan baik keputusan ekonomi, sosial maupun politik. Laporan keuangan diharuskan dapat memenuhi karakteristik kualitatif laporan keuangan. Terdapat dalam Peraturan Pemerintah (PP) No. 71 Tahun 2010 menjelaskan bahwa karakteristik kualitatif dari informasi terdapat dalam laporan keuangan terdiri dari relevan, andal, dapat dibandingkan dan dapat dipahami. Laporan keuangan bersifat relevan apabila informasi informasi yang terkandung di dalamnya mampu mempengaruhi keputusan pengguna dengan memberikan bantuan dalam mengevaluasi peristiwa masa lalu atau masa kini dan memprediksi masa depan serta mengoreksi hasil evaluasi dimasa lalu. Informasi yang relevan harus disajikan tepat waktu sehingga dapat berpengaruh dan berguna dalam pengambilan keputusan 
(Johnson1998) berpendapat bahwa dalam meminimalkan audit delay, pemimpin san auditor harus memenuhi ketepatan waktu pelaporan keuangan

Pada tahun pelaporan 2014 rata-rata audit delayatas laporan keuangan pemerintah di Indonesia dari 33 provinsi adalah 162 hari. Pada tahun pelaporan 2015 audit delay mengalami penurunan rata-rata 161 hari. Pada tahun pelaporan 2016-2017 rata-rataaudit delay menjadi 158 dan 157 hari. Pada tahun pelaporan 2018 rata-rata audit delay mengalami penurunan yaitu 156 hari. (sumber BPK). Pada tahun pelaporan 2014-2018 masih terdapat beberapa provinsi di indonesia yang mengalami keterlambatan penerbitan LKPD oleh BPK RI. Latar belakang penelitian ini juga disebabkan oleh ketidakkonsistenan hasil penelitian sebelumnya. Berdasarkan fenomena diatas, masih terdapat keterlambatan penyampaian LKPD dari batasan yang ditentukan dalam pasal 31 ayat 1 Undang-Undang Nomor 17 tahun 2003 tentang keuangan negara, yaitu enam bulan setelah tahun anggaran berakhir dan hasil penelitian sebelumnya belum konsisten mengenai faktor-faktor penyebab audit delay hal ini menarik untuk diteliti. Daerah yang dipilih dalam penelitian ini adalah seluruh Provinsi di Indonesia karena skalanya lebih besar dari Kota atau Kabupaten.

Berdasarkan uraian diatas maka penulis tertarik untuk melakukan penelitian tentang “ Pengaruh Ukuran Pemerintah, opini audit dan terpilihnya kembali kepala daerah sebelumnya (petahana/incumbent) terhadap audit delay pada pemerintah Provinsi di Indonesia".

\section{REVIEW LITERATUR DAN HIPOTESIS}

\section{Teori Value of Information}

Davis (dalam kadir, 2003:28) berpendapat bahwa informasi merupakan data yg diolah dan bermanfaat bagi penerima dalam mengambil keputusan baik sekarang maupun saat mendatang. Pratiwi (2010:12) berpendapat bahwa nilai merupakan sesuatu yang berharga bagi kehidupan manusia. Nilai informasi merupakan hal penting yang bermanfaat dalam membuat suatu keputusan untuk melakukan tindakan selanjutnya (Priyanto, 2013).

Informasi dibagi kedalam bentuk pengetahuan yang terekam, seseorang yang mendapatkan informasi serta mengalami perubahan dalam pengetahuannya dan secara pribadi yang dipegang oleh seseorang itu disebut informasi sebagai proses (Buckland dalam Pendit, 2003:33). Informasi dikatakan bernilai apabila manfaatnya lebih efektif dibanding dengan biaya untuk mendapatkannya. Sebagian besar informasi tidak dapat menaksir nilai efektifitas dari informasi tersebut. Faktor dalam menentukan nilai informasi adalah kemampuan untuk mengahasilkan dan menggunakan informasi serta keuntungan dari penggunaan informasi itu sendiri yang dapat disajikan dalam bentuk pita magnetik, jurnal, bentuk isian dan abstrak.

Berdasarkan uraian diatas, terlihat bahwa nilai teori informasi menekankan ketepatan waktu dalam penyajian informasi menekankan ketepatan waktu dalam menyajikan informasi pada saat informasi tersebut dibutuhkan. Informasi yang terlambat diterima, nilai kegunaannya akan lebih rendah, karena informasi yang cepat dan tepat akan lebih baik. Ketetapan waktu dalam menyampaikan laporan keuangan juga sebagai bentuk pertanggung jawaban pemerintah kepada masyarakat.

\section{Teori Keagenan (Agency Theori)}

Teori keagenan dikemukakan pertama kali oleh Jensen dan Mecling pada tahun 1976. Teori keagenan (agency theori) merupakan teori yang menjelaskan tentang hubungan keagenan antara dua pihak, dimana satu pihak tertentu (principal) mempekerjakan pihak lain (agent) untuk 
melaksanakan jasa atas nama mereka yang melibatkan adanya pendelegasian wewenang dalam pembuatan keputusan kepada agent ( Jensen dan meckling, 1976). Principal dalam hal ini adalah pemegang saham sedangkan agen adalah manajemen.

Siregar (2015) berpendapat bahwa teori keagenan tidak relevan dalam organisasi komersial dan tidak berkaitan dengan hubungan pemegang saham dan manajemen. Hubungan yang terjadi pada organisasi pemerintahan dan organisasi lainnya, ini yang dijelaskan oleh teori keagenan. Asumsi tentang sifat manusia, hubungan antar anggota organisasi dan asimetri informasi juga relevan dalam teori keagenen pada organisasi pemerintahan. Pada organisasi pemerintahan, publik adalah prinsipal. Dalam hal ini publik diwakili oleh dewan yang mewakili rakyat, sedangkan pengelola atau manajemen adalah pemerintah atau eksekutif.

Penggunaan standar akuntansi pemerintah diharapkan dapat meningkatkan ketetapan waktu laporan keuangan sehingga tidak terjadinya keterlambatan, sebagai bentuk pertanggung jawaban dari agen kepada prinsipal. Pemerintah daerah merupakan agen yang mendapat mandat untuk menyampaikan laporan keuangan kepada BPK. Ketepatan waktu penyampaian laopran keuangan dapat menjadi salah satu tolak ukur dari pertanggung jawaban pemerintah daerah sebagai agen kepada masyarakat yang sebagai prinsipal.

\section{Audit Delay}

Levantis dan Weetman et.al ( dalam Cohen dan Leventis, 2012) berpendapat bahwa audit delay merupakan waktu dari akhir tahun fiskal entitas sampai tanggal laporan audit. Aryanti (2005) dalam Sari setiawan dan ilham, (2014) berpendapat bahwa laporan audit keuangan tahunan diukur berdasarkan lamanya hari yang diperlukan dalam mendapatkan laporan keuangan auditor independen atas audit laporan keuangan sejak tanggal tutup buku, yaitu 31 Desember sampai tanggal yang tercantum pada laporan auditor independen.

Pada dasarnya untuk melihat ketepatan waktu, penelitian ini menggunakan 3 kriteria keterlambatan (Dyer dan Mc Hugh dalam Hilmi dan Ali, 2008) sebagai berikut:

\section{Preliminary lag}

Interval jumlah hari antara tanggal laporan keuangan sampai penerimaan laporan akhir preliminary oleh bursa. Dalam konteks sektor publik berarti tanggal laporan keuangan sampai tanggal penyerahan laporan keuangan kepada BPK.

\section{Auditors report lag}

Interval jumlah hari antara tanggal laporan keuangan sampai tanggal ditanda tanganinya laporan auditor.

\section{Total lag}

Interval jumlah hari antara tanggal laporan keuangan sampai tanggal di umumkannya tanggal penerimaan oleh bursa.

Ashton dan Elliot (1987) berpendapat bahwa adanya audit delay dipengaruhi oleh ketepatan waktu pelaporan keuangan dalam proses audit. Hal ini akan mempengaruhi tingkat ketidakpastian keputusan informasi yang di publikasikan dan pada akhirnya akan mengurangi nilai dari informasi itu sendiri.

\section{Ukuran Pemerintah}

Besar kecilnya ukuran pemerintah dilihat dari total pendapatan yang diperoleh dalam setahun (Kristanto, 2009). Hernawaty dan Rahayu (2014) bependapat bahwa perusahaan yang memiliki aset yang lebih besar melaporkan lebih cepat dibandingkan dengan perusahaan yang memiliki aset yang lebih kecil. Maksudnya perusahaan yang memiliki sumber daya yang besar akan 
mendapatkan lebih banyak sumber informasi, sistem informasi yang lebih canggih, sistem pengendalian internal yang lebih kuat, staf akuntansi yang hebat, pengawasan oleh investor serta regulator dan sorotan masyarakat yang diharapkan dapat melaporkan laporan keuangan audit lebih cepat ke publik.

Dalam konteks organisasi pemerintah Kabupaten/Kota yang besar juga cenderung memilki sumber daya yang lebih besar dari pada pemerintah kabupaten/kota yang lebih kecil yang memungkinkan mereka untuk menerapkan tertib administrasi dan pengelolaan keuangan daerah. Dari sudut pandang lain pemerintah yang memiliki sumber daya yang lebih besar biasanya menyusun laopran keuangan dan melaporkan hasil laporan auditnya lebih lambat dibandingkan dengan perusahaan yang memiliki aset kecil. Aset yang lebih besar dalam pemerintah memiliki jumlah transaksi yang lebih banyak sehingga hal tersebut menyebabkan semakin lambatnya proses pembuatan laporan keuangan dan proses auditnya.

Siregar (2015) berpendapat bahwa audit delay dapat berkurang dari ukuran pemerintah yang besar. Maksudnya ukuran pemerintah yang besar akan memiliki sumber informasi yang lebih banyak yang disertai dengan adanya pengawasan sehingga pemerintah melaporkan audit nya lebih cepat ke publik.

\section{Opini Audit}

Masdiantini dan Erawati (2016) berpendapat bahwa Opini audit adalah kesimpulan yang profesional dikeluarkan oleh auditor dalam menyajikan laporan keuangan secara wajar. Laporan keuangan opini BPK terdiri dari empat jenis yaitu, Wajar Tanpa Pengecualian (WTP), Wajar Dengan Pengecualian (WDP), Tidak Wajar (TW) dan Tidak Memberikan Pendapat (TMP). Mc Lelland dan Giroux (2000) berpendapat bahwa opini WTP adalah sebuah kabar baik yang akan di laporkan secepat munkin. Opini Wajar Tanpa Pengecualian (WTP) berarti auditor telah yakin bahwa pemerintah daerah bisa menyelenggarakan akuntansi secara baik dan benar sehingga tidak diperlukan prosedur tambahan. Opini Wajar Dengan Pengecualian berarti auditor yakin bahwa laporan keuangan berisikan suatu penyimpangan dari prinsip akuntansi yang berlaku secara umum yang berdampak material namun tidak mempengaruhi laporan keuangan secara keseluruhan. Opini Tidak Wajar (TW) berarti auditor telah yakin bahwa laporan keuangan tidak mencerminkan kondisi sebenarnya sehingga tidak diperlukan prosedur tambahan. Tidak memberikan pendapat (TMP) berarti adanya pembatasan ruang lingkup audit sehingga prosedur pemeriksaan tidak dapat dilaksanakan sepenuhnya. Hal tersebut akan menyebabkan proses pemeriksaan menjadi tepat waktu atau lebih cepat.

\section{Terpilihnya kembali kepala daerah sebelumnya (petahana/incumbent)}

Cohen dan Leventis (2013) berpendapat bahwa kepala daerah yang terpilih kembali lebih mngetahui mengenai langkah-langkah persiapan dalam memberikan fasilitas prosedur audit dan standar prosedur akuntansi. Kepala daerah yang terpilih kembali lebih banyak memiliki pengetahuan dari pada kepala daerah yang baru terpilih. Dengan pengalaman dan pengetahuan tersebut, terpilihnya kembali kepada daerah sebelumnya dapat membuat kebijakan yang mengarah pada perbaikan dalam prosedur akuntansi dan diharapkan akan mempercepat penyelesaian penyusunan laporan keuangan sehingga audit delay akan berkurang.

\section{Pengaruh Ukuran Pemerintah Terhadap Audit Delay}

Payne dan jensen (2002) berpendapat bahwa ukuran pemerintah yang besar akan mengalami audit delay lebih lama. Maksudnya dengan meningkatnya jumlah transaksi keuangan pada 
pemerintah kota. Aset pemerintah daerah memiliki transaksi keuangan yang lebih banyak dan nilainya lebih besar dibandingkan dengan aset daerah yang lebih kecil. Dengan transaksi keuangan yang lebih banyak maka diperlukannya waktu dalam pemeriksaan laporan keuangan. Berdasarkan uraian diatas, dalam penelitian ini diajukan hipotesis dengan rumus sebagai berikut H1: Ukuran pemerintah berpengaruh signifikan terhadap audit delay

\section{Pengaruh Opini Audit Terhadap Audit Delay}

Opini yang diberikan oleh BPK atas laporan keuangan pemerintah daerah berupa opini non WTP yaitu WDP, TW atau TMP yang dianggap catatan buruk kinerja keuangan pemerintah daerah yang bersangkutan. Sigit dan Fitriany (2014) berpendapat bahwa opini audit signifikan berpengaruh terhadap audit delay, karena setiap opini yang diberikan mempunyai masingmasing perbedaan seperti opini Wajar Dengan Pengecualina (WDP) berarti diperlukannya prosedur tambahan selama proses pemeriksaan untuk meningkatkan audit delay, Opini Wajar Tanpa Pengecualian (WTP) berarti auditor yakin bahwa pemerintah daerah telah melaksanakan akuntansi secara baik dan benar sehingga tidak memerlukan prosedur tambahan, Opini Tidak Wajar (TP) berarti laporan keuangan tidak mencerminkan kondisi yang sebenarnya sehingga tidak memerlukan prosedur tambahan dan Tidak memberikan pendapat berarti adanya pembatasan ruang lingkup audit sehingga prosedur pemeriksaan tidak dapat dilaksanakan sepenuhnya. Hal tersebut akan menyebabkan proses pemeriksaan menjadi tepat waktu atau lebih cepat. Berdasarkan uraian diatas, dalam penelitian ini diajukan hipotesis dengan rumus sebagai berikut :

H2: Opini audit berpengaruh signifikan terhadap audit delay

\section{Pengaruh Terpilihnya Kembali Kepala Daerah Sebelumnya (Petahana/Incumbent) terhadap Audit Delay}

Terpilihnya kembali kepala daerah sebelumnya (petahana/incumbent) diharapkan dapat mempercepat penyelesaian penyusunan laporan keuangan serta dapat mengurangi audit delay, karena terpilihnya kembali kepala daerah sebelumnya akan cukup akrab dengan standar dan prosedur akuntansi serta lebih mengetahui langkah-langkah persiapan yang diperlukan untuk memfasilitasi prosedur audit. Penelitian yang dilakukan oleh Wafa dan Nugreini (2017), Bae dan Wo (2016) berpendapat bahwa petahana/incumbent signifikan berpengaruh terhadap audit delay. Kepala daerah yang terpilih kembali lebih berpengalaman dalam pemerintahan yang bertugas dalam menyusun dan mengaudit laporan keuangan sehingga audit delay menjadi lebih pendek.. Berdasarkan uraian diatas, dalam penelitian ini diajukan hipotesis dengan rumus sebagai berikut : H3: Terpilihnya kembali kepala daerah sebelumnya (petahana/incumbent)

\section{Kerangka Konseptual}

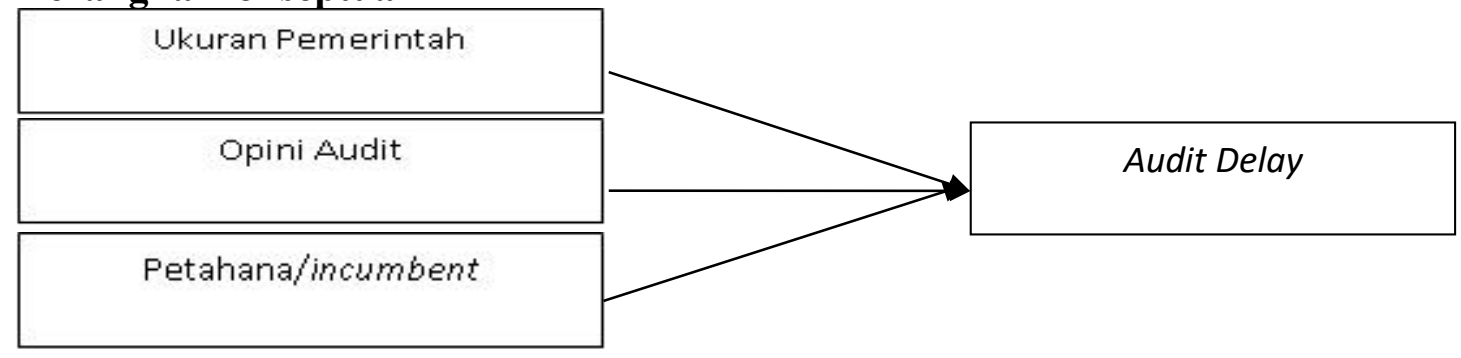

Gambar 1. Kerangka Konseptual 


\section{METODE PENELITIAN}

\section{Desain Penelitian}

Penelitian ini menggunakan pengujian hipotesis dengan analisis kuantitatif. Uji hipotesis merupakan uji statistik yang digunakan untuk menetukan apakah cukup bukti dalam sampel data untuk menyimpulkan bahwa suatu kondisi berlaku untuk keseluruhan populasi, perhitungan numerik (angka) untuk setiap variabel dibutuhkan dalam penelitian ini.

\section{Populasi dan Sampel}

Populasi dan sampel dalam penelitian ini adalah laporan keuangan Pemerintah Daerah (LKPD) di indonesia yang telah diaudit oleh BPK RI untuk periode tahun 2014 sampai dengan tahun 2018 yang berjumlah 33 provinsi.

\section{Jenis dan Sumber Data}

Penelitian menggunakan data sekunder berupa data dokumentar yaitu jumlah hari audit delay dan opini audit dari artikel-artikel yang diterbitkan oleh BPK, ukuran pemerintahan yang diukur dengan total aset diperoleh dari DJPK dan terpilihnya kembali kepala daerah sebelumnya (petahana/incumbent) dari wikipedia.com periode 2014-2018

\section{Variabel Penelitian dan pengukuran}

Variabel dependen dalam penelitian ini adalah audit delay dan variabel independen dalam penelitian ini adalah ukuran pemerintahan, opini audit dan petahana/incumbent. Dalam penelitian ini ukuran pemerintah di ukur menggunakan proksi Anggaran Belanja Daerah (APBD), opini audit di ukur menggunakan dummy jika pendapatannya WDP (1) dan selain WDP (0), incumbent diukur dengan dummy jika terpilih kembali (1) dan tidak terpilih kembali (0)

\section{Metode Analisis Data}

Analisis data pada penelitian ini diuji menggunakan program SPSS. Dengan menggunakan analisis multiple regression analysis.

$$
\mathrm{AD}=\alpha+\beta_{1} \mathrm{SIZE}+\beta_{2} \mathrm{OA}+\beta_{3} \mathrm{I}+\varepsilon
$$

\section{HASIL DAN PEMBAHASAN Analisis Statistik Deskriptif}

\section{Tabel 1}

Hasil statistik deskriptif

\begin{tabular}{|c|c|c|c|c|c|}
\hline \multicolumn{6}{|c|}{ Descriptive Statistics } \\
\hline & $\mathrm{N}$ & Minimum & Maximum & Mean & Std. Deviation \\
\hline $\log$ APBD & 165 & 11,83 & 14,11 & 12,9247 & 39178 \\
\hline $\mathrm{X} 2$ & 165 & 0 & 1 & ,11 & ,313 \\
\hline $\mathrm{X} 3$ & 165 & 0 & 1 & ,69 & 464 \\
\hline $\mathrm{Y}$ & 165 & 110 & 297 & 159,34 & 24,589 \\
\hline Valid N (listwise) & 165 & & & & \\
\hline
\end{tabular}

(Sumber: data diolah dengan SPSS)

Dari tabel diatas dapat dilihat bahwa rata-rata ukuran pemerintah yang diukur dengan logaritma natural dari total APBD diperoleh rata-rata sebesar 12,92. Nilai minimumnya adalah 
sebesar 11,83 (Provinsi Gorontalo) dan nilai maksimumnya adalah sebesar 14,11 (Provinsi DKI Jakarta). Standar deviasinya adalah 0,39.

Variabel Opini Audit yang diukur dengan dummy menunjukkan rata-rata sebesar 0,11 dengan nilai minimum sebesar 0,00 dan nilai maksimumnya sebesar 1,00 . Standar deviasinya adalah 0,31. Variabel incumbent yang dikukur dengan dummy menunjukkan rata-rata sebesar 0,69 dengan nilai minimum sebesar 0,00 dan nilai maksimumnya sebesar 1,00. Standar deviasinya adalah 0,46. Variabel audit delay yang dihitung dengan jumlah hari dari tanggal akhir tahun anggaran sampai tanggal diterbitkan LHP oleh BPK menunjukkan rata-rata 159,34, dengan nilai minimum sebesar 110,00 (Provinsi Sumatera Barat) yang artinya merupakan provinsi tercepat dalam menyampaikan laporan keuangan, dan nilai maksimumnya sebesar 297,00 (Provinsi Jambi) artinya merupakan provinsi yang paling lama dalam menyampaikan laporan keuangan. standar deviasinya adalah 24,58.

\section{Hasil Uji Normalitas}

Menurut Ghozali (2011) uji normalitas digunakan untuk menguji normalitas data yang digunakan untuk penelitian. Tujuan dari pengujian ini adalah untuk menguji apakah variabel dependen terdistribusi normal oleh masing-masing kelompok variabel independen. Dalam penelitian ini, normalitas diuji dengan uji Kolmogogrov-Smirnov (KS)

Data penelitian dikatakan menyebar normal atau memenuhi uji normal apabila nilai Asymp.Sig (2-tailed) variabel residual berada di atas 0.05. Sebaiknya, apabila nilai Asymp.Sig (2tailed) variabel residual berada di bawah 0,05 maka data tersebut tidak berdistribusi normal atau data tidak memenuhi uji normalitas ( Ghozali, 2011). Adapaun hasil pengolahan uji normalitas menggunakan Kolmogorof-Smirnov ( Uji K-S) ditunjukkan pada Tabel berikut :

\section{Tabel 2}

Hasil uji normalitas dengan uji Kolmogorov-Sminorv (KS)

\begin{tabular}{|c|c|c|c|c|c|}
\hline \multicolumn{6}{|c|}{ One-Sample Kolmogorov-Smirnov Test } \\
\hline & & $\log$ APBD & $\mathrm{X} 2$ & $\mathrm{X} 3$ & $\mathrm{Y}$ \\
\hline $\mathrm{N}$ & & 165 & 165 & 165 & 165 \\
\hline \multirow{2}{*}{$\begin{array}{l}\text { Normal } \\
\text { Parameters }{ }^{\mathrm{a}, \mathrm{b}}\end{array}$} & Mean & 12,9247 & ,11 & 69 & 159,34 \\
\hline & Std. Deviation & ,39178 & ,313 & ,464 & 24,589 \\
\hline \multirow{3}{*}{$\begin{array}{l}\text { Most Extreme } \\
\text { Differences }\end{array}$} & Absolute &, 086 &, 527 & ,438 &, 220 \\
\hline & Positive & 086 &, 527 &, 252 & ,220 \\
\hline & Negative &,- 055 &,- 364 &,- 438 &,- 186 \\
\hline \multicolumn{2}{|l|}{ Test Statistic } &, 086 & ,527 & ,438 & 220 \\
\hline \multicolumn{2}{|c|}{ Asymp. Sig. (2-tailed) } & $005^{\mathrm{c}}$ &, $000^{\mathrm{c}}$ &, $000^{\mathrm{c}}$ & $000^{\mathrm{c}}$ \\
\hline
\end{tabular}

a. Test distribution is Normal.

b. Calculated from data.

c. Lilliefors Significance Correction.

(Sumber : data diolah dengan SPSS)

Pada tabel 2 tersebut dapat kita lihat bahwa nilai signifikansi lebih besar dari 0,05 yaitu 0,00

\section{Hasil Uji Multikolinieritas}

Hasil uji multikolinieritas bertujuan untuk menguji apakah model regresi ditentukan adanya korelasi antar variabel bebas (independen). Untuk mengetahui ada tidaknya multikolinearitas dapat dilihat nilai VIF (Variable Inflation Factor) dan nilai tolerance. Jika nilai VIF $<10$ dan 
nilai tolerance $>0,01$ maka dapat disimpulkan tidak terjadi multikolinearitas. Pengujian multikolinearitas dapat dilihat pada Tabel berikut :

Tabel 3

Hasil Uji Multikolinieritas

Coefficients $^{\mathrm{a}}$

\begin{tabular}{|c|c|c|c|}
\hline \multirow[b]{3}{*}{ Model } & \multicolumn{2}{|c|}{ Coefficients $^{\mathrm{a}}$} & \\
\hline & \multicolumn{3}{|c|}{ Collinearity Statistics } \\
\hline & Tolerance & VIF & \\
\hline $\log$ APBD & ,963 & & 1,038 \\
\hline OA & ,927 & & 1,079 \\
\hline I & ,895 & & 1,118 \\
\hline a. Dependen & & & \\
\hline
\end{tabular}

Dari tabel 3 dapat dilihat bahwa semua variabel independen yaitu ukuran pemerintahan, opini audit dan petahana/incumbent memiliki nilai tolerance diatas dari 0,10 dan nilai VIF dibawah 10. Sehingga, dapat disimpulkan bahwa tidak terdapat gejala multikolinearitas antara variabel bebas, yang berarti semua variabel bebas dalam penelitian ini tidak memiliki pengaruh yang erat satu sama lain.

\section{Hasil Uji Heterokedastisitas}

Uji heterokedastisitas digunakan untuk menguji apakah model regresi terjadi ketidaksamaan variabel dari residual satu pengamatan ke pengamatan lainnya. Regresi yang baik seharusnya tidak terjadi heterokedastisitas. Jika varian dari residual satu pengamatan ke pengamatan lain tetap, maka disebut homokedastisitas dan jika berbeda disebut heterokedastisitas. Model regresi yang baik adalah homoskedastisitas atau tidak terjadi heteroskedastisitas (Ghozali, 2011). Pada penelitian ini, uji heterokedastisitas akan melihat pola titk-titik pada grafik regresi yang ditunjukkan pada gambar berikut :

Scatterplot

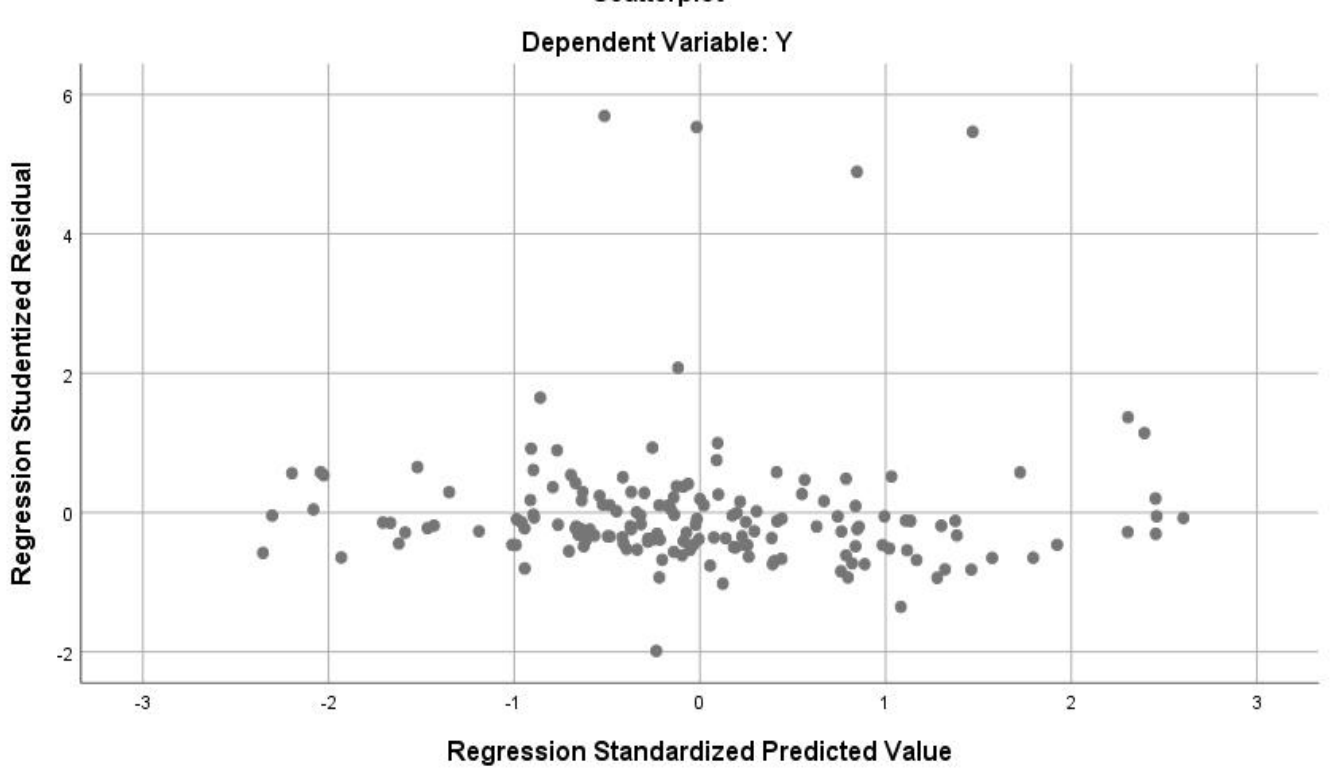

Gambar 2. Hasil Uji Heterokedastisitas (Sumber: data diolah dengan SPSS) 


\section{Hasil Uji Autokorelasi}

Uji autokorelasi bertujuan untuk mengetahui ada atau tidaknya korelasi antar data berdasarkan urutan waktu. Model regresi yang baik adalah regresi yang bebas dari autokorelasi. Dalam penelitian ini pengujian autokorelasi menggunakan nilai Durbin-Watson. Adapun hasil dari uji autokorelasi dapat dilihat pada tabel :

Tabel 4

Hasil uji autokorelasi menggunakan Durbint-Watson

\begin{tabular}{lccccc}
\hline \multicolumn{6}{c}{ Model Summary $^{\text {A }}$} \\
\hline Model & $\mathrm{R}$ & $\mathrm{R}$ Square & $\begin{array}{c}\text { Adjusted R } \\
\text { Square }\end{array}$ & $\begin{array}{c}\text { Std. Error of the } \\
\text { Estimate }\end{array}$ & Durbin-Watson \\
\hline 1 &, 16 &, 027 &, 009 & 24,480 & \\
& $4^{\mathrm{a}}$ & & & \\
\hline
\end{tabular}

Dari Tabel, dapat dilihat bahwa nilai Durbint-Watson (DW) adalah 1,845 yang berarti berada diantara -2 sampai +2 sehingga dapat disimpulkan bahwa tidak terdapat autokorelasi atau tidak ada korelasi antar data berdasarkan urutan waktu dan model regresi untuk penelitian ini dapat diterima.

\section{Regresi Linear berganda}

\section{Tabel 5}

\section{Regresi Linear Berganda}

\begin{tabular}{|c|c|c|c|c|c|c|}
\hline \multirow[b]{2}{*}{ Mod } & & \multicolumn{2}{|c|}{ Unstandardized Coefficients } & $\begin{array}{l}\text { Standardized } \\
\text { Coefficients }\end{array}$ & \multirow[b]{2}{*}{$\mathrm{T}$} & \multirow[b]{2}{*}{ Sig. } \\
\hline & & $\mathrm{B}$ & Std. Error & Beta & & \\
\hline \multirow[t]{4}{*}{1} & (Constant) & 269,658 & 64,926 & & 4,153 &, 000 \\
\hline & $\begin{array}{l}\log \text { APBD } \\
\text { (SIZE) }\end{array}$ & $-8,272$ & 4,972 &,- 132 & $-1,664$ & ,098 \\
\hline & $\mathrm{OA}$ & 3,617 & 6,350 &, 046 & ,570 &, 570 \\
\hline & $\mathrm{I}$ & $-5,498$ & 4,360 &,- 104 & $-1,261$ & ,209 \\
\hline
\end{tabular}

(Sumber: data diolah dengan SPSS)

Berdasarkan tabel diatas, didapatkan persamaan regresi sebagai berikut:

$$
\mathrm{AD}=269-8,27 \mathrm{SIZE}+3,61 \mathrm{OA}-\mathbf{5 , 4 9 8} \mathrm{I}
$$

Dari persamaan diatas, didapatkan pengolahan data sebagai berikut :

1. Nilai konstanta dalam penelitian ini adalah 269,658 artinya jika tidak memperhatikan ukuran pemerintahan, opini audit, dan petahana/incumbent maka audit delay mengalami lamanya sebesar 269.

2. Nilai koefisien regresi ukuran pemerintahan adalah $-8,27$ yang berarti bahwa besarnya APBD pemerintahan berbanding terbalik dengan audit delay, dimana setiap perubahan jumlah APBD maka audit delay akan mengalami peningkatan sebesar 8,27. 
3. Nilai koefisien regresi opini audit adalah 3,61 yang berarti bahwa opini audit berbanding lurus dengan dengan audit delay, dimana setiap perubahan opini audit selain WDP ke -WDP maka audit delay akan mengalami peningkatan sebesar 3,61.

4. Nilai koefisien regresi petahana/incumbent adalah $-5,49$ yang berarti bahwa petahana/incumbent berbanding terbalik dengan audit delay, dimana setiap peubahan petahana/incumbent maka audit delay akan mengalami penurunan sebesar 5,49

\section{Uji Kelayakan Model (Uji F)}

Uji F statistik menunjukkan apakah semua variabel independen yang termasuk dalam model berpengaruh terhadap variabel dependen atau independen (Ghozali, 2011). Jika nilai signifikan $>$ 0,05 berarti $\mathrm{H}$ di tolak tetapi jika nilai signifikan $<0,05$ berarti $\mathrm{H}$ diterima. Hasil uji-F adalah sebagai berikut :

\section{Tabel 6}

Hasil uji F-Test

\begin{tabular}{lllrrrr}
\hline \multicolumn{7}{c}{ ANOVA $^{\mathbf{a}}$} \\
\hline \multirow{2}{*}{ Model } & & $\begin{array}{c}\text { Sum of } \\
\text { Squares }\end{array}$ & Df & Mean Square & F & Sig. \\
\hline \multirow{2}{*}{1} & Regression & 2671,586 & 3 & 890,529 & 1,486 &, $220^{\text {b }}$ \\
\cline { 2 - 8 } & Residual & 96483,408 & 161 & 599,276 & & \\
\cline { 2 - 7 } & Total & 99154,994 & 164 & & & \\
\hline
\end{tabular}

a. Dependent Variable: Y

b. Predictors: (Constant), X3, log_APBD, X2

(Sumber : data diolah dengan SPSS)

Berdasarkan Tabel diatas, dapat dilihat nilai F-Test signifikan $0,220>0,05$. Hal ini berarti uji model variabel independen yaitu ukuran pemerintah, opini audit, dan petahana/incumbent tidak berpengaruh tehadap audit delay.

\section{Koefisien Determinan (R)}

Nilai Adjusted (R) adalah sebesar 0,009. Hal ini menunjukkan bahwa besarnya kemampuan variabel independen, yaitu ukuran pemerintah, opini audit, dan petahana/incumbent dalam menjelaskan variabel dependen, yaitu audit delay adalah sebesar 10,5\%. Sedangkan 89,5\% dipengaruhi ataupun dijelaskan oleh variabel-variabel lain diluar model penelitian ini seperti ukuran perusahaan, temuan audit dan akuntabilitas kinerja. Nilai adjusted $\mathrm{R}$ dapat dilihat pada Tabel sebagai berikut :

Tabel 7

Hasil koefisien determinasi

\begin{tabular}{|c|c|c|c|c|c|}
\hline \multicolumn{6}{|c|}{ Model Summary } \\
\hline Model & $\mathrm{R}$ & R Square & $\begin{array}{l}\text { Adjusted R } \\
\text { Square }\end{array}$ & $\begin{array}{l}\text { Std. Error of the } \\
\text { Estimate }\end{array}$ & Durbin-Watson \\
\hline 1 &, $164^{\mathrm{a}}$ &, 027 & ,009 & 24,480 & 1,845 \\
\hline \multicolumn{6}{|c|}{ a. Predictors: (Constant), X3, log APBD, X2 } \\
\hline \multicolumn{6}{|c|}{$\begin{array}{l}\text { b. Dependent Variable: Y } \\
\text { sumber : data diolah dengan SPSS }\end{array}$} \\
\hline
\end{tabular}

(Sumber: data diolah dengan SPSS) 


\section{Uji Signifikan terhadap Parameter Individu (t-Test)}

Pengujian t-test digunakan untuk mengetahui pengaruh masing-masing variabel independen terhadap variabel dependen (Ghozali, 2011). Jika sig < 0,05 maka hipotesis diterima, sedangkan jika sig $>0,05$ maka hipotesis ditolak. Hasil uji $-\mathrm{t}$ adalah sebagai berikut :

Tabel 8

Hasil uji t

\begin{tabular}{|c|c|c|c|c|c|c|}
\hline \multirow[b]{2}{*}{ Moc } & & \multicolumn{2}{|c|}{ Unstandardized Coefficients } & $\begin{array}{l}\text { Standardized } \\
\text { Coefficients }\end{array}$ & \multirow[b]{2}{*}{$\mathrm{T}$} & \multirow[b]{2}{*}{ Sig. } \\
\hline & & $\mathrm{B}$ & Std. Error & Beta & & \\
\hline \multirow[t]{4}{*}{1} & (Constant) & 269,658 & 64,926 & & 4,153 &, 000 \\
\hline & $\begin{array}{l}\log _{\mathrm{D}} \mathrm{APB} \\
\mathrm{D}\end{array}$ & $-8,272$ & 4,972 &,- 132 & $-1,664$ & ,098 \\
\hline & $\overline{\mathrm{OA}}$ & 3,617 & 6,350 & ,046 &, 570 &, 570 \\
\hline & $\mathrm{I}$ & $-5,498$ & 4,360 &,- 104 & $-1,261$ & 209 \\
\hline
\end{tabular}

a. Dependent Variable: $\mathrm{Y}$

sumber : data diolah dengan SPSS

Berdasarkan hasil pengujian $\mathrm{H} 1$ pada Tabel diatas dapat dilihat bahwa ukuran pemerintahan memiliki nilai signifikan sebesar $0,098>0,05$ dengan koefisien regresi adalah 8,272. Ini berarti bahwa ukukran pemerintahan tidak berpengaruh signifikan terhadap audit delay, sehingga hipotesis pertama (H1) ditolak. Berdasarkan hasil pengujian hipotesis $\mathrm{H} 2$ pada Tabel diatas dapat dilihat bahwa opini audit memiliki nilai signifikan sebesar 0,570 >0,05 dengan koefisien regresi adalah 3,617. Artinya bahwa opini audit tidak berpengaruh signifikan terhadap audit delay, sehingga hipotesis kedua (H2) ditolak. Berdasarkan hasil pengujian $\mathrm{H} 3$ pada Tabel diatas dapat dilihat bahwa petahana/incumbent memiliki nilai signifikan sebesar 0,209 $>0,05$ dengan koefisien regresi adalah $-5,498$. Ini berarti bahwa petahana/incumbent tidak berpengaruh signifikan terhadap audit delay, sehingga hipotesis ketiga (H3) ditolak.

\section{Pembahasan}

\section{1) Pengaruh Ukuran pemerintahan terhadap audit delay}

Berdasarkan uji regresi linear berganda terhadap ukuran pemerintahan didapat hasil koefisien regresi sebesar -8,27 dimana setiap perubahan APBD maka audit delay akan mengalami peningkatan sebesar 8,27 . Hasil uji t statistik ukuran pemerintahan memiliki nilai signifikansi sebesar 0,098 >0,05 yang dapat disimpulkan bahwa ukuran pemerintahan yang diproksikan dengan besarnya APBD tidak berpengaruh signifikan terhadap audit delay. Penelitian ini tidak konsisten dengan penelitian-penelitian sebelumnya yang menggunakan total asset sebagai proksi ukuran pemerintahan (Payne dan Jensen (2002), Muhammad dan Suzan (2016), Hernawaty dan Rahayu (2014), serta Puspitasari dan Latrini (2014)).

Namun penelitian ini konsisten dengan penelitian yang dilakukan oleh Akbar (2017) yang menggunakan total asset sebagai proksi ukuran pemerintahan menemukan bahwa ukuran pemerintahan tidak berpengaruh signifikan terhadap audit delay. Ukuran pemerintahan tidak berpengaruh signifikan terhadap audit delay dikarenakan semakin besar APBD yang dimiliki pemerintah daerah maka semakin pendek audit delay yang terjadi. Pemerintahan daerah dengan APBD yang besar akan menerapkan teknologi informasi yang mutakhir pada perencanaan sampai dengan proses evaluasi dalam pengelolaan keuangan daerahnya, pengendalian internal yang lebih kuat serta pengawasan dari investor dan masyarakat sehingga audit delay dapat dihindari. Hasil penelitian ini juga membuktikan bahwa ukuran pemerintah daerah yang besar 
bukan menjadi alasan bagi pemerintah daerah untuk tidak tepat waktu dalam penyampaian laporan keuangan.

\section{2) Pengaruh Opini audit terhadap audit delay}

Berdasarkan uji regresi linear berganda terhadap opini audit didapat hasil koefisien regresi sebesar 3,61 dimana setiap perubahan opini audit selain WDP ke-WDP maka audit delay akan mengalami peningkatan sebesar 3,61. Hasil uji t statistik opini audit memiliki nilai signifikansi sebesar 0,570 >0,05 yang dapat disimpulkan bahwa opini audit tidak signifikan berpengaruh terhadap audit delay. Penelitian ini konsisten dengan penelitian Sigit dan Fitriany (2014), Muhammad dan Suzan (2016), Che-ahmmad dan Shamharir (2008), serta Ari (2014). Namun hasil penelitian ini tidak konsisten dengan penelitian yang dilakukan oleh Kartika (2011), Rustiarini dan Sugarti (2013), Trisnakati dan Charistine (2008), Lucyanda (2013).

Opini audit berpengaruh terhadap audit delay karena setiap opini yang diberikan mempunyai jenis yang berbeda-beda seperti opini wajar dengan pengecualian (WDP) mengindikasikan diperlukannya prosedur tambahan selama proses pemeriksaan yang dapat meningkatkan audit delay. Opini wajar tanpa pengecualian (WTP) berarti auditor telah yakin bahwa pemerintah daerah telah menyelenggarakan akuntansi secara baik dan benar sehingga tidak diperlukan prosedur audit tambahan. Opini tidak wajar (TW) menunjukkan bahwa auditor telah yakin bahwa laporan keuangan tidak mencerminkan kondisi yang wajar. Tidak memberikan pendapat (TMP) berati adanya pembatasan ruang lingkup audit dan auditor tidak mendapatkan bukti yang cukup dan tepat sehingga prosedur pemeriksaan tidak dapat dilaksanakan sepenuhnya. Hal tersebut akan menyebabkan proses pemeriksaan menjadi tepat waktu atau lebih cepat sehingga akan mempersingkat audit delay.

\section{3) Pengaruh Terpilihnya Kembali Kepala Daerah Sebelumnya (Petahana/incumbent) terhadap Audit Delay}

Berdasarkan uji regresi linear berganda terhadap petahana/incumbent didapat hasil koefisien regresi sebesar -5,49 dimana setiap perubahan kepala daerah yang tidak terpilih menjadi terpilih kembali maka audit delay akan mengalami peningkatan sebesar -5,69. Hasil uji t statistik petahana/incumbent memiliki nilai signifikansi 0,209 >0,05 yang dapat disimpulkan bahwa petahana/incumbent tidak berpengaruh signifikan terhadap audit delay. Penelitian ini tidak konsisten dengan penelitian Wafa dan Nugreini (2017), Bae dan Wo (2016) yang menemukan petahana/incumbent berpengaruh signifikan terhadap audit delay.

Namun hasil penelitian ini konsisten dengan penelitian yang dilakukan oleh Karlina dan Gamayumi (2018), Rachmawi (2016), Muladi (2014) yang menemukan bahwa petahana/incumbent tidak berpengaruh signifikan terhadap audit delay. Petahana/incumbent tidak berpengaruh terhadap audit delay didasarkan mekanisme reward dan punishment terhadap ketepatan waktu penyampaian LKPD sangat minim dan kurangnya komitmen seorang pemimpin kepala daerah terhadap kualitas laporan keuangan pemerintah daerah, dikarenakan semakin tinggi komitmen dari seorang pimpinan terhadap LKPD maka semakin tinggi kualitas LKPD yang dihasilkan dikarnakan ada keinginan yang kuat dari kepala daerah untuk menghasilkan LKPD yang handal dan berkualitas juga dibantu dengan tim yang bekerja dengan baik dan berkomitmen menghasilkan laporan keuangan yang berkualitas. Dengan adanya komitmen yang tinggi maka proses dalam penyusunan laporan keuangan akan berjalan dengan baik sehingga akan mengurangi audit delay, (Mahlil dan Yahya, 2016). 
Dalam penelitian ini terjadi ketiga hipotesis yang tidak signifikan, hai ini dikarenakan dari data yang dihasilkan, ukuran pemerintah, opini audit dan petahana/incumbent memiliki nilai signifikan yang lebih besar dari 0,05 sehingga ketiga hipotesis ini dinyatakan tidak signifikan terhadap audit delay (ditolak), di dukung oleh penelitian terdahulu yang sudah terbukti tidak berpengaruh signifikan terhadap audit delay, namun pada penelitian lain diperoleh hasil sebaliknya bahwa ukuran pemerintah, opini audit dan petahana/incumbent berpengaruh signifikan terhadap audit delay. Dengan adanya tinjauan penelitian yang didukung dan ditolak tersebut, bisa dijelaskan bahwa paling tidak hasil penelitian ini relevan dengan penelitian terdahulu seperti penelitian akbar (2017), sigit dan fitriany (2014), karlina dan gamayumi (2018) dan berbeda dengan penelitian payne dan jensen (2002), Rustiarini dan sugarti (2013), wafa dan nugreini (2017).

\section{KESIMPULAN, KETERBATASAN DAN SARAN Kesimpulan}

Hasil pengujian hipotesis dengan menggunakan analisis regresi berganda dengan variabel dependen adalah audit delay dan variabel independen yaitu ukuran pemerintahan, opini audit, dan petahana/incumbent menunjukan bahwa:

a. Ukuran pemerintahan yang diproksikan dengan APBD tidak berpengaruh

signifikan terhadap audit delay. Hal ini dikarenakan pemerintahan daerah dengan APBD yang besar akan memiliki sistem informasi yang baik dan pengendalian internal yang lebih kuat sehingga proses audit akan lebih cepat maka audit delay akan menjadi lebih pendek, serta pengawasan dari investor dan masyarakat yang memungkinkan pemerintahan untuk melaporkan laporan keuangan audit nya lebih cepat kepublik. Hasil penelitian ini juga membuktikan bahwa ukuran pemerintah daerah yang besar bukan menjadi alasan bagi pemerintah daerah untuk tidak tepat waktu dalam penyampaian laporan keuangan.

b. Opini audit berpengaruh signifikan terhadap audit delay. Hal ini dikarenakan setiap opini yang diberikan mempunyai kriteria yang berbeda-beda seperti opini wajar dengan pengecualian (WDP) mengindikasikan diperlukannya prosedur tambahan selama proses pemeriksaan yang dapat meningkatkan audit delay. Opini wajar tanpa pengecualian (WTP) berarti auditor telah yakin bahwa pemerintah daerah telah menyelenggarakan akuntansi secara baik dan benar sehingga tidak diperlukan prosedur audit tambahan. Opini tidak wajar (TW) menunjukkan bahwa auditor telah yakin bahwa laporan keuangan tidak mencerminkan kondisi yang wajar. Tidak memberikan pendapat (TMP) berarti adanya pembatasan ruang lingkup audit dan auditor tidak mendapatkan bukti yang cukup dan tepat sehingga prosedur pemeriksaan tidak dapat dilaksanakan sepenuhnya.

c. Petahana/incumbent tidak berpengaruh signifikansi terhadap audit delay. Hal ini dikarenakan kurangnya komitmen soerang pemimpin dalam mencapai kualitas laporan keuangan pemerintah daerah. Semakin tinggi komitmen dari seorang pimpinan terhadap LKPD maka semakin tinggi kualitas LKPD yang dihasilkan dikarnakan ada keinginan yang kuat dari kepala daerah untuk menghasilkan LKPD yang handal dan berkualitas juga dibantu dengan tim yang bekerja dengan baik dan berkomitmen menghasilkan laporan keuangan yang berkualitas. Dengan adanya komitmen yang tinggi maka proses dalam penyusunan laporan keuangan akan berjalan dengan baik sehingga akan mengurangi audit delay. 


\section{Keterbatasan Penelitian}

Berdasarkan hasil penelitian dan kesimpulan, maka penelitian ini masih terdapat beberapa keterbatasan antara lain sebagai berikut:

a. Pemilihan variabel yang berpengaruh terhadap audit delay adalah ukuran pemerintahan, opini audit, dan petahana/incumbent. Dari hasil penelitian tidak ada yang berpengaruh terhadap audit delay. Hal ini memungkinkan terdapat faktor-faktor lain yang mempengaruhi seperti temuan audit maupun akuntabilitas kinerja.

b. Periode pengamatan dalam penelitian ini hanya selama lima tahun pengamatan, yakni dari tahun 2014 sampai dengan tahun 2018.

c. Penelitian ini hanya menggunakan tanggal penyerahan LHP oleh BPK-RI ke DPRD karena penyelesaian LHP adalah sebelum tanggal penyerahannya.

\section{Saran}

Adapun saran yang dapat direkomendasikan atas dasar hasil penelitian dan pembahasan yang telah dipaparkan sebelumnya antara lain sebagai berikut:

a. Opini audit berpengaruh signifikan terhadap audit delay hal ini diharapkan diperlukannya prosedur tambahan selama proses pemeriksaan yang dapat meningkatkan audit delay, karena setiap opini yang diberikan mempunyai jenis yang berbeda-beda.

b. Penelitian selanjutnya diharapkan memakai periode penelitian yang lebih lama dengan menambah tahun penelitian.

c. Penelitian selanjutnya diharapkan juga dapat mengembangkan variabel independen yang digunakan. Pengembangan ini perlu dilakukan mengingat banyak variabel lain yang berperan dalam mempengaruhi audit delay Seperti temuan audit dan akuntabilitas kinerja.

d. Penelitian selanjutnya diharapkan untuk memperhatikan tanggal penyerahan laporan keungan dari pemerintah ke BPK-RI.

\section{DAFTAR PUSTAKA}

Al-ghanem, W. dan Hegazy, M. 2011. An Empirical Analysis of Audit Delayand Timeliness of Corporate Financial Reporting in Kuwait. Eurasian Business Review, 1,73-90.

Amani, F. Althaf. dan I. Waluyo. 2016. Pengaruh ukuran perusahaan, profitabilitas, opini audit, dan umur perusahaan terhadap Audit Delay. Jurnal Nominal Vol 5(1):135-150.

Angruningrum, S. dan Wirakusuma, M. Gede. 2013. Pengaruh profitabilitas, Leverage kompleksitas operasi, reputasi KAP, dan komite audit pada audit delay. E-Jurnal Akuntansi Universitas Udayana 5(2):251-270.

Akbar, F. 2017. Analisis pengaruh ukuran pemerintah daerah, opini audit dan Leverage terhadap audit delay pada kabupaten/kota di indonesia. E-Jurnal Fakultas Ekonomi Universitas Lampung

Asih, G. Yuli. dan Pratiwi, M. M. Shinta 2010. Perilaku Prososial ditinjau dari Empati dan Kematangan Emosi. Jurnal Psikologi, Volume I, No 1. Kudus:Universitas Muria Kudus.

Azis, A. Abdul., Isa, F., dan Abu, M. Faizal. 2014. Audit Report Lags of Federal Statutory Bodiesin Malaysia. Recent Advancesin Economics Management and Development, ISBN:978-1061804-217-0. 
Bustamam dan Maulana, K. 2013. Pengaruh Leverage, Subsidiaries dan Audit Complexity terhadap Audit Delay. Jurnal Telaah dan Riset Akuntansi, Vol3(2) : 110-122.

Bae, C. dan Woo, Y. Sang. 2016. The effect of CEO turnover on audit report lag and management discretionary report lag : evidence from korea. Invesment management and financial innovations, Vol 13(1).

Che-ahmad, A. dan Abidin, S. 2008. Audit Delay of listed companies A case of Malaysia International Business Research Vol 1(4):32-39.

Christian, I. dan Ilaboya, O. 2014. Corporate governance and Audit Report Lag in Negeria International Journal of Humanities and Social Science, Vol 4(13):172-180.

Craslaw, C. Charles. dan Kaplan, S. 1991. An Examination of Audit Delay: Further Evidence from NewZeland. Accounting and Bussiness Research, 22(82): 21-32.

Cohen, S. dan Leventis, S. 2012. Effects Of Municipal, Auditing and Political Factors on Audit Delay. Accounting Forum, 37 (2013): 40-53.

Davis, G. 2003. Sistem Informasi Manajemen. Yogyakarta.

Dyer, J. dan McHugh, A. 1975. The Timeliness of the Australian Annual Report. Juornal of of Accounting Research. Vol 13. Hal 204219 Chicago: University Of Chicago.

Faricha, A. Nur. dan Ardini, L. 2017. Analisis faktor-faktor yang mempengaruhi audit delay Jurnal Umum dan Riset Akuntansi Vol 6(8) : 1-7

.Halim, A. 2007. Akuntansi Sektor Publik: Akuntansi Keuangan Daerah. Jakarta salemba Empat.

Hemingway, J. dan Tom, G. 2000. The Value of Information Systems Teaching and Researc In The Knowledge Society. Informing Science, Vol 3 no 4, 167-184.

Hernawati, C. dan Rahayu, S. 2014. Pengaruh Ukuran Perusahaan, Tingkat leverage dan Kualitas kantor akuntan public terhadap Audit Delay. Eproceeding of management vol 3(3):371-387.

Hilmi, Utari, dan Ali, S. 2008. Analisis Faktor-Faktor yang Mempengaruhi Ketepatan waktu Penyampaian Laporan Keuangan (Studi Empiris pada PerusahaanPerusahaan yang Terdaftar Di BEJ Periode 2004-2006). Simposium Nasional Akuntansi XI Surabaya.

Irefin dan Mechanic, A. Mohammed. 2014. Effect of Employee Commitment on Organizational Performance in Coca Cola Nigeria Limited Maiduguri, Borno State. IOSR Journal Of Humanities And Social Science (IOSR-JHSS)Volume 19(13): 2279-0845.

Janarta, W. dan Supraso, B. 2016. Pengaruh Ukuran Perusahaan, Keberadaan Komite Audit dan Leverage terhadap Audit Delay. E-Jurnal Akuntansi Universitas Udayana Vol 16(3) : 2374-2407.

Johnson, E. Laurence. 1998. Further Evidence On The Determinants of Local Goverment Audit Delay. Journal of Public Budgeting, Accounting \& Financial Management, 10 (3): 375-397.

Jogiyanto. 2005. Analisa dan Desain Sistem Informasi : Pendekatan Terstruktur Teori dan Praktek Bisnis. Penerbit Andi, Yogjakarta.

Kadir, A. 2003. Pengenalan Sistem Informasi. Penerbit Andi, Yogyakarta.

Kartika, A. 2011. Faktor-faktor yang mempengaruhi audit delay pada perusahaan manufaktur yang terdaftar di BEI. Dinamika Keuangan dan Perbankan Vol 3(2):152-171.

Karlina, Lindrinasari, dan Gamayumi, R. Rika. 2018. Determinant analysis of audit report lag in regional government in Indonesia. International Journal of Scientific \& Technology Research, Vol 7(4) : 2277-8616.

Kasidi. 2016. Hubungan antara komitmen kepemimpinan dan budaya organisasi dengan 
kinerja guru di smp negeri sekecamatan putri hijau. Manajer Pendidikan Vol 10(3):287214.

Kristanto dan Septian, B. 2009. Pengaruh Ukuran Pemerintahan, Pendapatan Asli Daerah (PAD), dan Belanja Modal Sebagai Prediktor Kelemahan Pengendalian Internal. Jurnal Akuntansi, 9(1):41-62.

Kristanto dan Andri, 2003. Perancangan Sistem Informasi dan Aplikasinya. Penerbit Gaya Media, Yogjakarta.

Lista, W. dan Mushawir. 2016. Analisis Faktor-faktor yang Mempengaruhi Audit Delay. SRAMB, UMB Yogyakarta Vol 2(2):22:32.

Lucyanda, J. 2013. Pengujian faktor-faktor yang mempengaruhi Audit Delay. Jurnal Akuntansi dan Auditing, Vol 9(2):128-149.

Mahlil dan Yahya, R. 2016. Pengaruh Komitmen Kepala Daerah dan Pengetahuan akuntansi Terhadap Kualitas Laporan Keuangan Pemerintah Daerah Provinsi Aceh. Jurnal Ilmiah Mahasiswa Ekonomi Akuntansi (JIMEKA) Vol. 2, No.2

Masdiantini, P. dan Adi, N. Made. 2016. Pengaruh Ukuran Pemerintah Daerah, kemakmuran Intergovernmental Revenue, Temuan dan Opini Audit BPK pada kinerja keuangan. EJurnal Akuntansi Universitas Udayana, 14:11501182.

McLelland. J. Andrew., dan Gary. 2000. An Empirical Analysis of Auditor Report Timing by Large Municipalities. Journal of Accounting and Public Policy, 19 (3): 263-281.

Muhammad, F. dan Suzan, L. 2016. Pengaruh ukuran perusahaan, opini auditor \& kualitas kantor akuntan public terhadap audit delay. e-proceeding ofmanagement, vol 3(2):1665-1667.

Owusu, Ansah, Stephen, dan Leventis. 2006. Timeliness of Corporate Annual Financial Reporting in Greece. European Accounting Review, 15 (2): 273287.

Payne. L. Jeff., dan Kevan, K. 2002. An Examination of Municipal Audit Delay. Journal of Accounting and Public Policy. Vol 21. Hal 1-29 Oklahoma: University of Oklahoma.

Pendit, N. 2003. Ilmu Pariwisata, Sebuah Pengantar Perdana. Jakarta: Penerbit Pradya Paramita.

Puspitasari, K. Dian. dan Latrini, M. 2014. Pengaruh ukuran perusahaan, leverage dan ukuran KAP terhadap Audit Delay. E-Jurnal Akuntansi Universitas Udayana ,Vol 8(2):283-299.

Respatiningsih, I \& Sudirjo, S. 2015. Pengaruh komitmen organisai, kapabilitas dan kepuasa kerja terhadap kinerja pegawai (Studi Empirik Pada Inspektorat Kabupaten Pemalang). Serat Acitya - Jurnal Ilmiah UNTAG

Semarang ISSN : 2302-2752, Vol. 4 No. 3. 